\title{
Quantitation of spermatogenesis by DNA flow cytometry: Comparative study among six species of mammals
}

\author{
R SURESH, G R ARAVINDAN and N R MOUDGAL* \\ Primate Research Laboratory, Center for Reproductive Biology and Molecular \\ Endocrinology, Indian Institute of Science, Bangalore 560 012, India
}

MS received 13 May 1992; revised 27 October 1992

\begin{abstract}
Suspensions of testicular germ cells from six species of mammals were prepared and stained for the DNA content with a fluorochrome (ethidium bromide) adopting a common technique and subjected to DNA flow cytometry. While uniform staining of the germ cells of the mouse, hamster, rat and monkey could be obtained by treating with $0.5 \%$ pepsin for $60 \mathrm{~min}$ followed by staining with ethidium bromide for $30 \mathrm{~min}$, that of the guinea pig and rabbit required for optimal staining pepsinization for $90 \mathrm{~min}$ and treatment with ethidium bromide for $60 \mathrm{~min}$. The procedure adopted here provided a uniform recovery of over $80 \%$ of germ cells with each one of the species tested and the cell population distributed itself according to the DNA content (expressed as $\mathrm{C}$ values) into 5 major classesspermatogonia (2C), cells in S-phase, primary spermatocytes (4C), round spermatids (1C), and elongating/elongated spermatids (HC). Comparison of the DNA distribution pattern of the germ cell populations between species revealed little variation in the relative quantities of cells with $2 \mathrm{C}(8-11 \%)$, S-phase $(6-9 \%)$, and $4 \mathrm{C}(6-9 \%)$ amount of DNA. Though the spermatid cell populations exhibited variations (1C:31-46\%, $\mathrm{HCl}: 7-$ $20 \%$ and and $\mathrm{HC} 2: 11-25 \%)$ they represented the bulk of germ cells (70-80\%). The overall conversion of $2 \mathrm{C}$ to $1 \mathrm{C}(1 \mathrm{C}: 2 \mathrm{C}$ ratio) and meiotic transformation of $4 \mathrm{C}$ cells to $1 \mathrm{C}$ (1C:4C ratio) kinetics were relatively constant between the species studied. The present study clearly demonstrates that DNA flow cytometry can be adopted with ease and assurance to quantify germ cell transformation and as such spermatogenesis by analysing a large number of samples with consistency both within and across the species barrier. Any variation from the norms in germ cell proportions observed following treatment, for e.g. hormonal stimulation or deprivation can then be ascribed due to a specific effect of the hormone/drug on single/multiple steps in germ cell transformation.
\end{abstract}

Keywords. Testicular germ cells; mammals; DNA flow cytometry; germ cell transformation kinetics.

\section{Introduction}

In the field of male reproductive biology there is an acute need for a suitable method which can provide rapid, sensitive, and quantitative measurement of various testicular germ cell types. Such information could help assess the status of spermatogenic process under various experimental/pathological conditions including that produced by a contraceptive under test. Flow cytometry combines many of the advantages of microscopy and biochemical analysis in a single high precision technique for rapid phenotypic and genotypic analysis of individual cells using a limited quantity of the tissue as available at biopsies. Since the DNA content of the germ cells changes distinctly during the various steps of proliferation and transformation in spermatogenesis, DNA flow cytometry offers a method to

*Corresponding author 
monitor with relative ease such changes in dispersed testicular cells. Flow cytometric analysis of testes of the mouse (Toppari et al 1988), rat (Clausen et al 1978a, b, 1979, 1982; Toppari et al 1986; Van Kroonenburgh et al 1986; Vaishnav 1988), monkey (Aravindan et al 1990) and the human (Thorud et al 1980) has been carried out but the methods of cell preparation, fluorochromes/stains used and the flow cytometer employed as well have been different. The present study was undertaken with a view to determine the extent to which the technique developed in our laboratory for one species (i.e., the monkey) using a Beckton- Dickinson flow cytometer (FACScan) for analysis and ethidium bromide (EB) to fluorescence tag the DNA can be adopted to the other commonly used laboratory species of mammals, and whether the germ cell preparation of different species show any distinct variation in the per cent germ cells recovered and their transformation ratios.

\section{Materials and methods}

\subsection{Animals}

Five sexually mature adult males from each of the following species were included in the study: mouse, rat, hamster, guinea pig, rabbit and monkey. Except bonnet monkeys (Macaca radiata) which were from the colony maintained at the Primate Research Laboratory, the rest of the species were obtained from the Central Animal Facility of the Institute. All the animals were maintained under a regulated light: dark (12:12h) schedule with food and water provided ad lib.

\subsection{Chemicals and solutions}

Dulbecco's phosphate buffered saline (PBS, pH 7.4) was obtained from Hi-media, Bombay, India; pepsin from Serva Heidelberg, Germany; EB, ribonuclease (RNase) and Nonidet p-40 (NP-40) from Sigma Chemical Co., St. Louis, Mo, USA; Ketamine hydrochloride was from Parke-Davis, Detroit, MI, USA, and Sodium pentabarbitone from May and Baker, England.

\subsection{Germ cell preparation}

The testicular tissue was obtained either by biopsy (monkeys) or by unilateral castration (rabbits), or by euthenising the animals. Care was taken to select the same region of the testis (contralateral to the epididymis) while removing the tissue in all the instances. The testicular tissue, ranging from 50-100 mg was immediately transferred to a petridish containing a small volume of PBS, finely minced, passed gently through the hub of a syringe and then vortexed briefly to maximise the release of germ cells from the seminiferous tubule minces. The cell suspension was then filtered using a nylon filter (Nybolt P-25, Swiss Silk, Zurich, Switzerland) and a drop of the filtrate was observed under the microscope to check the number and integrity of the released germ cells before fixing in $80 \%$ chilled ethanol and storing at $4^{\circ} \mathrm{C}$ until analysis. 


\subsection{DNA staining and flow cytometry}

The staining procedure followed was essentially similar to that routinely used for the monkey germ cells in our laboratory except for different durations of treatment. Briefly, the fixed cells were washed with the buffer and equal concentration of cells was taken and incubated with $0.5 \%$ pepsin in isotonic PBS $(\mathrm{pH} 2 \cdot 0)$ for 60,90 or $120 \mathrm{~min}$ at $37^{\circ} \mathrm{C}$. After centrifugation at $900 \mathrm{~g}$ for $10 \mathrm{~min}$, to the cell pellet was added $200 \mu 1$ of staining solution (25 $\mu \mathrm{g}$ EB, $0.004 \%$ RNase and $0.3 \%$ NP-40 in PBS, final $\mathrm{pH} \mathrm{7.4)} \mathrm{and} \mathrm{left} \mathrm{in} \mathrm{the} \mathrm{dark} \mathrm{at} \mathrm{room} \mathrm{temperature} \mathrm{for} 30,45$, or $60 \mathrm{~min}$. Treating with pepsin beyond 120 min resulted in the loss of population identity in the flow cytogram. The concentration of RNase used here is far in excess of that used by Toppari et al $(1988,5 \mu \mathrm{g} / \mathrm{ml})$ and has been found to be adequate to remove any contaminating RNA that may interfere with the coefficient of variation of the DNA peaks analysed. The flow cytometer used was a FACScan (Beckton-Dickinson) equipped with an air-cooled 15 milliwatt Argon-Ion laser at $488 \mathrm{~nm}$ and the emitted light from the cell samples (EB stained) was detected at $545 \mathrm{~nm}$ on FL2. Uniform number of cells $(10,000 /$ sample at a flow rate of 600-700 events/s) were acquired and analysed for the per cent germ cell populations and their transformation kinetics, expressed as ratios. The different populations of germ cells thus obtained based on the relative fluorescence intensities of their DNA content were expressed as $\mathrm{C}$ values using human peripheral blood leucocytes as the diploid standard (Otto et al 1984). The values are expressed as mean \pm SEM.

\section{Results}

Five different populations of germ cells characteristic of sexually mature adult testis could be identified in all the species studied (figure 1). Based on the relative fluorescence intensities of the DNA content the cell populations were classified as spermatogonia (2C), pre-leptotene spermatocytes (S-phase), primary spermatocytes $(4 \mathrm{C})$, round spermatids $(1 \mathrm{C})$, and elongating $(\mathrm{HCl})$ and elongated $(\mathrm{HC} 2)$ spermatids. Once the location of $2 \mathrm{C}$ population of cells in the flow cytogram is arrived at by analysing flow cytometrically a human peripheral lymphocyte preparation, the $1 \mathrm{C}$ and $4 \mathrm{C}$ populations were ascertained on the corresponding fluorescence intensities of their DNA contents.

Of the various species tested, the mouse, rat, hamster and monkey germ cells required a $60 \mathrm{~min}$ pepsinization followed by a $30 \mathrm{~min}$ exposure to $\mathrm{EB}$ to provide an optimal flow cytogram. That of guinea pig and rabbit, however, required a longer period of treatment (pepsinization/EB exposure-90/60 min) to provide a comparable flow cytogram (figure 1).

Of the total of 10,000 cells acquired per sample approximately $83 \%(83 \cdot 21 \pm 4 \cdot 22-$ SD) constituted the various populations of germ cells that could be clearly discernible indicating that the recovery of germ cells by the procedure adopted here is fairly uniform, reproducible and good (table 1). In all cases the germ cells could primarily be categorised under two types - those having 1C amount of DNA represented in the flow cytogram as $1 \mathrm{C}, \mathrm{HCl}$ and $\mathrm{HC} 2(70-80 \%$ of the total population) and those having $2 \mathrm{C}$ to $4 \mathrm{C}(20-30 \%)$ amount of DNA, The latter is seen as two distinct peaks $-2 \mathrm{C}$ and $4 \mathrm{C}$, the cells in between these two peaks being 


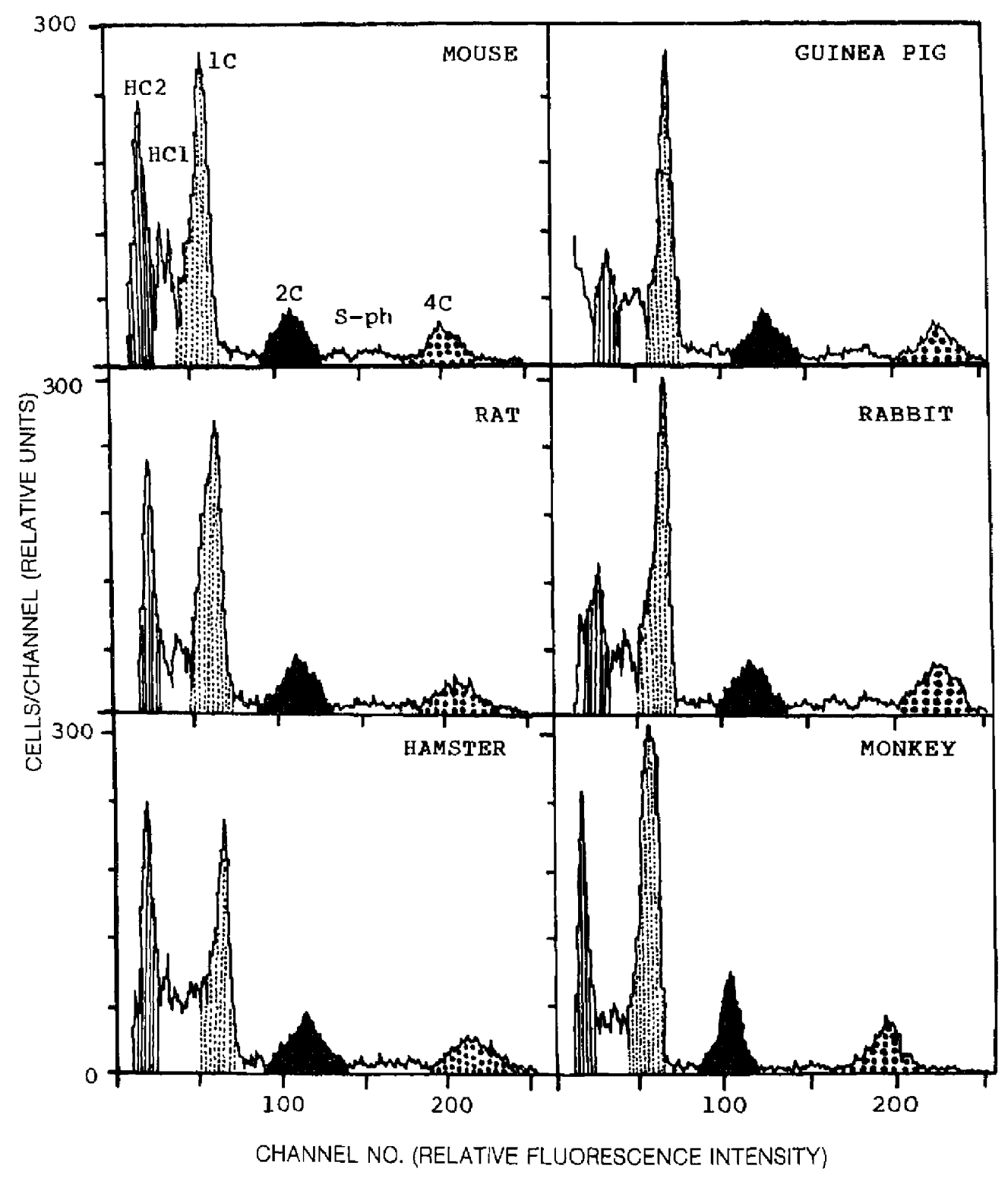

Figure 1. Representative flow cytograms showing the distribution of testicular germ cell populations based on their DNA content in the six species of mammals studied by DNA flow cytometry.

characterized as those in S-phase (figure 1) The categorization of $\mathrm{HCl}$ and $\mathrm{HC} 2$ is based on the differences in fluorescence intensities of the spermatid populations appearing before the $1 \mathrm{C}$ peak indicating that due to continued compaction spermatid DNA undergo during spermiogenesis, they bind lesser than normal amount of EB (Clausen et al 1982).

The 2C population of cells which might include besides spermatogonia a small 
Table 1. Per cent testicular germ cell populations in six species of mammals analysed by DNA flow cytometry.

\begin{tabular}{|c|c|c|c|c|c|c|c|c|c|}
\hline \multirow[b]{3}{*}{ Species* } & \multirow{3}{*}{$\begin{array}{c}\text { Total \% GC } \\
\text { recovered/ } \\
10,000 \text { cells } \\
\end{array}$} & \multicolumn{8}{|c|}{ Germ cell populations $(\%)^{\S}$} \\
\hline & & \multicolumn{4}{|c|}{ Haploids } & \multicolumn{4}{|c|}{ Non-haploids } \\
\hline & & HC2 & $\mathrm{HCl}$ & $1 \mathrm{C}$ & Total & $2 \mathrm{C}$ & S-phase & $4 \mathrm{C}$ & Total \\
\hline $\begin{array}{l}\text { Mouse } \\
\text { (Mus musculus) }\end{array}$ & $\begin{array}{r}89.3 \\
\pm \quad 0.5\end{array}$ & $\begin{array}{r}24 \cdot 3 \\
\pm \quad 1 \cdot 6\end{array}$ & $\begin{array}{r}16 \cdot 3 \\
\pm \quad 1 \cdot 8\end{array}$ & $\begin{array}{r}39 \cdot 0 \\
\pm 2 \cdot 1\end{array}$ & $\begin{array}{r}79.8 \\
+\quad 1.9\end{array}$ & $\begin{array}{r}8.5 \\
\pm 0.5\end{array}$ & $\begin{array}{r}6.1 \\
\pm 0.5\end{array}$ & $\begin{array}{r}5.8 \\
\pm 0.3\end{array}$ & $\begin{array}{r}20-2 \\
\pm \quad 0.8\end{array}$ \\
\hline $\begin{array}{l}\text { Rat } \\
\text { (Rattus norvagicus) }\end{array}$ & $\begin{array}{r}83.1 \\
\pm \quad 1.7\end{array}$ & $\begin{array}{r}20 \cdot 2 \\
\pm 1 \cdot 6\end{array}$ & $\begin{array}{r}18.4 \\
\pm 1.4\end{array}$ & $\begin{array}{r}38.4 \\
\pm 1.4\end{array}$ & $\begin{array}{r}77.0 \\
+\quad 2.1\end{array}$ & $\begin{array}{r}8.2 \\
\pm 0.6\end{array}$ & $\begin{array}{r}7.6 \\
\pm 0.7\end{array}$ & $\begin{array}{r}7.2 \\
\pm 0.5\end{array}$ & $\begin{array}{r}23 \cdot 0 \\
\pm 0-3\end{array}$ \\
\hline $\begin{array}{l}\text { Hamster } \\
\text { (Mesocricetus auratus) }\end{array}$ & $\begin{array}{r}86.3 \\
\pm \quad 2.5\end{array}$ & $\begin{array}{r}26.8 \\
\pm \quad 20\end{array}$ & $\begin{array}{r}17 \cdot 4 \\
\pm 3 \cdot 4\end{array}$ & $\begin{array}{r}31 \cdot 1 \\
\pm \quad 26\end{array}$ & $\begin{array}{r}75.3 \\
\pm \quad 1.6\end{array}$ & $\begin{array}{r}9 \cdot 0 \\
\pm 1 \cdot 1\end{array}$ & $\begin{array}{r}7.9 \\
\pm 0.9\end{array}$ & $\begin{array}{r}7.8 \\
\pm 0.9\end{array}$ & $\begin{array}{r}24.7 \\
\pm \quad 1.2\end{array}$ \\
\hline $\begin{array}{l}\text { Guinea pig } \\
\text { (Cavia porcellus) }\end{array}$ & $\begin{array}{r}77.3 \\
+\quad 3.0\end{array}$ & $\begin{array}{r}11 \cdot 2 \\
\pm \quad 3 \cdot 1\end{array}$ & $\begin{array}{r}18 \cdot 3 \\
\pm 2-9\end{array}$ & $\begin{array}{r}43.7 \\
\pm \quad 2.7\end{array}$ & $\begin{array}{r}73 \cdot 2 \\
\pm \quad 2 \cdot 3\end{array}$ & $\begin{array}{r}9.5 \\
\pm 0.1\end{array}$ & $\begin{array}{r}9.3 \\
\pm 1.2\end{array}$ & $\begin{array}{r}7.0 \\
\pm 0.3\end{array}$ & $\begin{array}{r}25.8 \\
\pm 1.6\end{array}$ \\
\hline $\begin{array}{l}\text { Rabbit } \\
\text { (Oryctolagus } \\
\text { cuniculus) }\end{array}$ & $\begin{array}{r}80.5 \\
\pm \quad 1.4\end{array}$ & $\begin{array}{r}13 \cdot 3 \\
\pm 2 \cdot 2\end{array}$ & $\begin{array}{r}19 \cdot 3 \\
\pm \quad 1.6\end{array}$ & $\begin{array}{r}39 \cdot 4 \\
\pm 1 \cdot 3\end{array}$ & $\begin{array}{r}72.0 \\
\pm 1.6\end{array}$ & $\begin{array}{r}10.8 \\
\pm 0.4\end{array}$ & $\begin{array}{r}8.9 \\
\pm 0.9\end{array}$ & $\begin{array}{r}8 \cdot 3 \\
\pm 0 \cdot 3\end{array}$ & $\begin{array}{r}28.0 \\
\pm \quad 1.1\end{array}$ \\
\hline $\begin{array}{l}\text { Monkey } \\
\text { (Macaca radiata) }\end{array}$ & $\begin{array}{r}82.8 \\
\pm \quad 1.2\end{array}$ & $\begin{array}{r}20 \cdot 4 \\
\pm \quad 1.4\end{array}$ & $\begin{array}{r}7.8 \\
\pm 0.4 \\
\end{array}$ & $\begin{array}{r}46.4 \\
\pm \quad 1.8\end{array}$ & $\begin{array}{r}74.6 \\
\pm \quad 2.1\end{array}$ & $\begin{array}{r}9.8 \\
\pm 0.4 \\
\end{array}$ & $\begin{array}{r}7.4 \\
\pm 1.0\end{array}$ & $\begin{array}{r}8.2 \\
\pm 0.6\end{array}$ & $\begin{array}{r}25.4 \\
\pm \quad 1.5\end{array}$ \\
\hline
\end{tabular}

$*_{n}=5 /$ species.

${ }^{\S}$ Germ cell populations were calculated considering the total $\%$ recovery values as $100 \%$. Values are Mean \pm SEM.

population of somatic cells (Leydig/Sertoli cells) that may get liberated during cell preparation procedure adopted accounted in all species to $10 \%$ or less (table 1). The spermatocyte population $(4 \mathrm{C})$ as well as the cells in S-phase also showed a remarkable uniformity across the species barrier (table 1). The transformation kinetics of germ cell populations is presented as ratios in table 2 . The $1 \mathrm{C}: 2 \mathrm{C}$ ratios which provide the overall turnover of spermatogonial cells to round spermatids are relatively constant between species. The 4C: 2C, 4C: S-phase, and $1 \mathrm{C}$ : 4C ratios also show reasonable consistency. The variations seen in the ratios of $\mathrm{HC} 2: 1 \mathrm{C}$ (elongated: round spermatids) and $\mathrm{HC} 2: \mathrm{HC} 1$ (elongated: elongating spermatids) probably reflect the differences in the rate of transformation of the round spermatids to elongating/elongated spermatids between species.

Table 2. Kinetics of germ cell transformations (ratios) in the six species of mammals studied by DNA flow cytometry.

\begin{tabular}{|c|c|c|c|c|c|c|}
\hline \multirow[b]{2}{*}{ Species* } & \multicolumn{6}{|c|}{ Germ cell ratios } \\
\hline & $1 \mathrm{C}: 2 \mathrm{C}$ & $4 C: 2 C$ & $4 C: S-p h$ & $1 C: 4 C$ & $\mathrm{HC} 2: 1 \mathrm{C}$ & $\mathrm{HC} 2: \mathrm{HCl}$ \\
\hline Mouse & $4 \cdot 64 \pm 0 \cdot 26$ & $0.68 \pm 0.02$ & $0.93 \pm 0.09$ & $6.84 \pm 0.50$ & $0.63 \pm 0.05$ & $1.62 \pm 0.24$ \\
\hline Rat & $4.68 \pm 0.19$ & $0.87 \pm 0.01$ & $0.83 \pm 0.09$ & $5.33 \pm 0.30$ & $0.53 \pm 0.05$ & $1 \cdot 09 \pm 0 \cdot 10$ \\
\hline Hamster & $3 \cdot 50 \pm 0 \cdot 24$ & $0.86 \pm 0.04$ & $0.98 \pm 0.13$ & $4.01 \pm 0.45$ & $0.86 \pm 0.40$ & $1 \cdot 54 \pm 0.21$ \\
\hline $\begin{array}{c}\text { Guinea } \\
\text { pig }\end{array}$ & $4 \cdot 60 \pm 0 \cdot 44$ & $0.73 \pm 0.03$ & $0.75 \pm 0.09$ & $6.24 \pm 0.43$ & $0.26 \pm 0.08$ & $0.62 \pm 0.19$ \\
\hline Rabbit & $3 \cdot 70 \pm 0 \cdot 12$ & $0.77 \pm 0.03$ & $0.93 \pm 0.08$ & $4.96 \pm 0.13$ & $0.34 \pm 0.06$ & $0.69 \pm 0.15$ \\
\hline Monkey & $4 \cdot 70 \pm 0 \cdot 70$ & $0.83 \pm 0.09$ & $1 \cdot 06 \pm 0.17$ & $5 \cdot 66 \pm 0.87$ & $0.43 \pm 0.01$ & $2 \cdot 61 \pm 0.30$ \\
\hline
\end{tabular}

$*_{n}=5 /$ species

Values are mean \pm SEM. 


\section{Discussion}

The primary objective of this investigation was to determine if the procedure worked out for analysing testicular germ cells of one species by flow cytometry is easily adaptable for other laboratory animal species. This has been adequately demonstrated by the results of the current study. It is interesting that the results of the present study are essentially similar to that reported earlier by us for the rat (Vaishnav et al 1988) and the monkey (Aravindan et al 1990) using a different fluorochrome (DAPI) and a different flow cytometer (Phywe ICP-22, Phywe A G, Goettingen, Germany). Though the rate of transformation of one germ cell type to another in different species appears similar, they also exhibit subtle differences (for e.g. in spermiogenesis - $\mathrm{HC} 2: 1 \mathrm{C}$ and $\mathrm{HC} 2$ : $\mathrm{HC} 1$ ratios) and this may reflect differences between the species in the time taken for completion of one spermatogenic cycle. Several recent studies by our group (Vaishnav et al 1988; Moudgal et al 1988; Aravindan and Moudgal 1991; Aravindan et al 1991; Suresh and Moudgal 1992; Jeyakumar et al 1992) as well as others (Isoyama 1986; Weinbauer et al 1991) have shown using DNA flow cytometric analytical procedures that testicular germ cell transformations are amenable to alteration by specific hormonal deprivation or stimulation suggesting thereby that this would be an efficient and accurate method to investigate problems on regulation of spermatogenesis. As the results obtained across the species barrier as demonstrated here are uniform and reproducible, any changes observed in germ cell transformation as a consequence of hormonal stimulation/deprivation or drug treatment will be significant and contribute to the understanding of the action of the hormone/drug. We have, in addition, noted that the DNA distributions from biopsy samples taken from six different loci on the same testis of a monkey reveal no significant differences in the per cent germ cell populations of $2 \mathrm{C}(10-12 \%)$, S-phase $(5-7 \%)$ and $4 \mathrm{C}(6-8 \%)$. The spermatid population, however, exhibited some variation (1C:36-46\%; $\mathrm{HCl}: 18-28 \%$; HC2:9-14\%) between the regions. Such regional differences in the spermatid population have also been reported following analysis of biopsy samples from the human testis (Clausen et al 1978b). Besides, the kinetics of germ cell transformation showed little variation between the anterior, posterior, right, and left regions of the testis where as the dorsal and ventral regions showed minor differences in the $1 \mathrm{C}: 2 \mathrm{C}$ and $1 \mathrm{C}: 4 \mathrm{C}$ ratios. Based on the observations of Thorud et al (1980) and our own observations in the rabbit (Jeyakumar et al 1992) and monkey (Suresh and Moudgal 1992), it is clear that flow cytometric analysis of one or two biopsy samples could be adequate to provide a true picture of the status of spermatogenic activity. Besides species as well as sexual maturity of the test animal determining the specific hormonal effect, it is becoming increasingly clear that hormones like FSH and testosterone regulate spermatogenesis by influencing transformation of specific but different germ cell types (Suresh and Moudgal 1992; Jeyakumar et al 1992). In infertile men, therefore, a pretherapy flow cytometric analysis of testicular germ cell population may help determine the lesion and the therapy that has to be resorted to restore normal spermatogenesis.

\section{Acknowledgements}

This work was supported by grants from the Indian Council of Medical Research and the Department of Biotechnology, New Delhi, to the Centre for Advanced 
Research in Reproductive Biology at the Institute. One of us (RS) is thankful to the Indian Institute of Science for the award of a Research Associateship.

\section{References}

Aravindan G R and Moudgal N R 1991 FSH deprivation affects spermatogenesis and sperm quality in the adult nonhuman primate; in Immunology - Perspective in reproduction and infection (ed.) $\mathrm{S} \mathrm{K}$ Gupta (New Delhi: Oxford and IBH) pp 227-232

Aravindan G R, Ravindranath N and Moudgal N R 1991 Use of DNA flow cytometry in assessing gonadotropin regulation of spermatogenesis in monkeys; in Perspectives in primate reproductive biology (eds) N R Moudgal, K Yoshinaga, A J Rao and P R Adiga (New Delhi: Wiley Eastern) pp 189-199

Aravindan G R, Ravindranath N, Gopalakrishnan K and Moudgal N R 1990 DNA flow cytometric analysis of testicular germ cell populations of the bonnet monkey ( $M$. radiata) as a function of sexual maturity; J. Reprod. Fertil. 89 397-406

Clausen O P F, Purvis K and Hansson V 1978a Microflow fluorimetric DNA measurement of isolated testicular cells from the rat; Ann. Biol. Anim. Biochim. Biophys. 18 541-546

Clausen O P F, Purvis K and Hansson V 1978b Quantitation of spermatogenesis by flow cytometric DNA measurments; Int. J. Androl. Suppl. 2 513-521

Clausen O P F, Purvis K and Hansson V 1979 Endocrine correlates of meiosis in the male rat; Arch. Androl. 2 59-66

Clausen O P F, Parvinen M and Krikhus B 1982 Stage-related variations in DNA fluorescence distribution during rat spermatogenic cycle measured by flow cytometry; Cytometry 2 421-425

Isoyama R 1986 DNA flow cytometric evaluation of spermatogenesis of the rebound phenomenon with testosterone in adult male rats; Hinyokika Kiyo 32 981-988

Jeyakumar M, Suresh R and Moudgal N R 1992 Changes in testicular function associated with specific deprivation of luteinising hormone/testosterone in the rabbit; International Conference on Fertility Regulation, IRR, Bombay, India (Abstr.)

Moudgal N R, Ravindranath N, Aravindan G R, Dighe R R and Murthy G S 1988 Anti-FSH antibody as a probe in determining the role of FSH in the maintenance of gonadal function in the primate; in Nonsteroidal gonadal factors: physiological roles and possibilities in contraceptive development (eds) G D Hodgen, Z Rosenwaks and J M Spieler (CONRAD Program) pp 249-257

Otto F J, Oldiges H and Jain V K 1984 Flow cytometric measurement of cellular DNA content dispersion induced by mutagenic treatment; in Biological dosimetry (eds) W G Eisert and $\mathrm{M}$ L Mendelson (Heidelberg: Springer-Verlag) pp 37-49

Suresh R and Moudgal N R 1992 Nocturnal serum testosterone surge has a regualtory effect on meiotic/post meiotic transformation of testicular germ cells in the bonnet monkey (M. radiata); International Conference on Fertility Regulation, IRR, Bombay, India (Abstr.)

Thorud E, Clausen O P F and Abyholm T 1980 Fine needle aspiration biopsies from human testis evaluated by DNA flow cytometry: Acta Pathol. Microbiol. Scand. (Suppl.) Series A-Flowcytometry 4 175-177

Toppari J, Bishop P C, Parker J W and diZerega G S 1988 DNA flow cytometric analysis of mouse seminiferous epithelium; Cytometry 9 456-462

Toppari J, Mali P and Eerola E 1986 Rat spermatogenesis in vitro traced by quantitative flow cytometry; J. Histochem. Cytochem. 34 1029-1035

Vaishnav Mahima Y 1988 Studies on regulation of testicular function by gonadotropins: Regulation of spermatogenesis and Leydig cell function in the rat by follicle stimulating hormone; $\mathrm{Ph} \mathrm{D}$ thesis, Indian Institute of Science, Bangalore

Vaishnav M Y, Gnanakan A and Moudgal N R 1988 Effect of FSH deprivation on spermatogenesis in the adult rat and monkey: Assessment by DNA flow cytometry; Proc. 8th Int. Congr. Endocrinol, Kyoto, Japan, (Abstr. 16-18-044)

Van Kroonenburgh M J, Van Gasterin H J, Beck J L and Herman C J 1986 A computer model of spermatogeneis in the rat: correlation with flow cytometric data based on autoradiographic cell-cycle properties; Cell Tissue Kinet. 19 171-177

Weinbauer G F, Behre H M, Fingscheidt U and Neischlag E 1991 Human follicle stimualting hormone exerts a stimulatory effect on spermatogenesis, testicular size, and serum inhibin levels in the gonadotropin-releasing hormone antagonist-treated non human primate; Endocrinology 129 981-988 